\title{
THE PSYCHOGENIC BASIS OF DYSPEPSIA IN THE ABSENCE OF ORGANIC DISEASE
}

\author{
LIEUTENANT-COLONEL D. M. ROBERTS, M.D., F.R.C.P.E., R.A.M.C.
}

\section{Royal Army Medical College, Millbank}

SUMMARY: Fifty-two patients presenting with dyspepsia for which no organic cause could be found, thirty-one patients admitted to hospital because of the effects of alcohol abuse (some of whom suffered dyspepsia), and nineteen healthy controls were assessed to see whether psychogenic factors in the family history or among the early environmental influences were of aetiological significance and to elucidate concurrent psychosomatic conditions and personality types.

Factors significantly associated with functional dyspepsia included a family history of dyspepsia, childhood emotional deprivation and concurrent headaches, insomnia and a subjective liability to exaggerated mood swings. On psychometric testing patients suffering from functional dyspepsia were found to have an abnormally high degree of neuroticism.

Alcohol abusers who suffer from dyspepsia, when compared to those who do not, were more prone to mood swings, had a higher degree of neuroticism on testing and were more likely to have a history of psychiatric illness. This suggests that personality may in some way influence the expression of dyspepsia even in this organic syndrome.

\section{Introduction}

The syndrome in which dyspepsia is attributable to no demonstrable organic disease has been given many names, including "non-ulcer dyspepsia", "nervous dyspepsia", "X-ray negative dyspepsia" and "functional dyspepsia". The dyspeptic symptoms have sometimes been arbitrarily and uncritically attributed to organic disease for which no firm evidence existed, such as "chronic gastritis" or "biliary dyskinesia"; the former an asymptomatic condition and the latter a very dubious entity (Brummer 1969).

The aetiology of the syndrome is unknown, but psychogenic factors have often been suspected of playing a part. In the present study some possible psychogenic factors have been assessed by comparing a group of dyspeptics without organic disease, hereafter referred to as functional dyspetics (F.D.) with controls. A group of alcolohics was also assessed in order to examine the possible psychogenic factors influencing the development of dyspepsia in a situation in which it is usually attributed to an organic cause, but where phychogenic factors are known to operate.

\section{Patients and methods}

One hundred and two male servicemen were assessed, comprising 52 patients presenting with dyspepsia for which no organic cause could be found, 31 patients admitted to hospital because of the effects of prolonged excessive intake of alcohol, and 19 apparently healthy controls. Dyspepsia was defined as a complaint 
of epigastric pain or severe discomfort associated with one or more of the following symptoms: nausea, vomiting, heartburn, flatulence and fulness or distension after meals.

Organic disease was sought by full physical examination and investigation which included barium meal, gastric biopsy, haematological and biochemical profile (including liver function tests), augmented histamine test, serum folate and vitamin B12 estimation, tests of intestinal absorption and, in some cases, jejunal biopsy.

A history of past, especially childhood, psychogenic illness was sought in the form of recurrent bowel disturbance, recurrent vomiting or psychiatric disturbance sufficiently severe to warrant medical treatment. Childhood emotional deprivation (C.E.D.) was defined and quantitated as follows:-

1 point =emotional deprivation within an intact family group.

2 points $=$ exclusion of the child from the family for a minimum period of one year.

3 points $=$ loss of one parent before the age of 15 years.

4 points $=$ loss of both parents before the age of 15 years.

Other factors assessed included the experiencing of headaches, smoking habits, consumption of analgesics, the individual's own assessment of his liability to mood swings, insomnia, and a family history of dyspepsia, alcohol abuse or psychiatric disturbance sufficiently severe to warrant medical treatment.

Most individuals completed a Maudsley Personality Inventory (M.P.I.) (Eysenck 1959) which measures Neuroticism and Extroversion and also a Shipley Hartford Retreat Scale which provides a measure of mental deterioration corrected for educational attainment.

\section{Results}

Results published elsewhere (Roberts 1972) have shown that alcohol is a cause of histological chronic gastritis but that chronic gastritis is not a cause of dyspeptic sympitoms in either the alcoholic or the F.D. group.

Table I compares the incidence of certain features of the present status, the past history and the family history in, on the one hand, patients with F.D. and controls, and on the other hand, alcohol abusers with and without dyspepsia.

The incidence of headaches, insomnia, mood swings, a history of C.E.D., and a family history of dyspepsia are significantly higher in the F.D. group than in controls. There is no significant difference between the F.D. group and controls in the incidence of cigarette smoking, analgesic consumption (figures not presented), childhood recurrent bowel disturbance, childhood recurrent vomiting, a past history of psychiatric illness, a family history of alcohol abuse or a family history of psychiatric illness.

Within the alcoholic group the only differences of statistical significance were the higher incidence of mood swings and a family history of psychiatric illness in those with dyspepsia, compared with those without dyspepsia. 


\section{Table I}

Comparison of some features of the present status, past history and family history in patienț with functional dyspepsia and controls and in alcohol abusers with and without dyspepsiaio

\begin{tabular}{|c|c|c|c|c|c|c|c|c|c|c|c|c|}
\hline & \multirow[b]{2}{*}{$\begin{array}{c}\text { No. of } \\
\text { cases } \\
\text { unless } \\
\text { otherwise } \\
\text { specified }\end{array}$} & \multicolumn{4}{|c|}{ Present status } & \multicolumn{4}{|c|}{ Past history } & \multirow{2}{*}{ 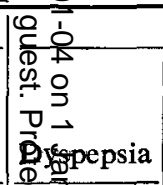 } & \multicolumn{2}{|c|}{ Family history } \\
\hline & & $\begin{array}{l}\text { Cigarette } \\
\text { smoking }\end{array}$ & Headaches & Insomnia & $\begin{array}{l}\text { Mood } \\
\text { swings }\end{array}$ & $\begin{array}{c}\text { Childhood } \\
\text { recurrent } \\
\text { bowel } \\
\text { disturbance }\end{array}$ & $\begin{array}{l}\text { Childhood } \\
\text { recurrent } \\
\text { vomiting }\end{array}$ & $\begin{array}{l}\text { Physchi- } \\
\text { atric } \\
\text { illness }\end{array}$ & $\begin{array}{c}\text { Childhood } \\
\text { emotional } \\
\text { depriva- } \\
\text { tion }\end{array}$ & & $\begin{array}{l}\text { Alcohol } \\
\text { abuse }\end{array}$ & $\begin{array}{l}\text { Psychi- } \\
\text { atric } \\
\text { illness }\end{array}$ \\
\hline Controls & 19 & $\begin{array}{c}14 \\
(73.7 \%)\end{array}$ & $(21.1 \%)$ & $(10.5 \%)$ & $(31.6 \%)$ & - & $(5.3 \%)$ & $(10.5 \%)$ & $\stackrel{5}{\text { points }}$ & 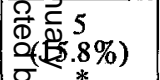 & $(10.5 \%)$ & $\begin{array}{c}6 \\
(31.6 \%)\end{array}$ \\
\hline Dyspeptics & 51 & $\begin{array}{c}38 \\
(74.5 \%)\end{array}$ & $\begin{array}{c}24 \\
(47.1 \%)\end{array}$ & $\begin{array}{c}18 \\
(35.3 \%)\end{array}$ & $\begin{array}{c}32 \\
(62.8 \%)\end{array}$ & $\begin{array}{c}5 \\
(9.8 \%)\end{array}$ & $\begin{array}{c}6 \\
(11.8 \%)\end{array}$ & $\begin{array}{c}6 \\
(11.8 \%)\end{array}$ & $\begin{array}{c}43 \\
\text { points }\end{array}$ & 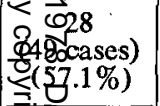 & $\begin{array}{c}13 \\
(48 \text { cases }) \\
(27.1 \%)\end{array}$ & $\begin{array}{c}12 \\
(48 \text { cases }) \\
(25.0 \%)\end{array}$ \\
\hline $\begin{array}{l}\text { Alcohol } \\
\text { abusers } \\
\text { without } \\
\text { dyspepsia }\end{array}$ & 18 & $\begin{array}{c}17 \\
(94.4 \%)\end{array}$ & $\begin{array}{c}7 \\
(38.8 \%)\end{array}$ & $\begin{array}{c}10 \\
(55.5 \%)\end{array}$ & $\begin{array}{c}7 \\
(38.8 \%)\end{array}$ & - & - & - & $\begin{array}{c}23 \\
\text { points }\end{array}$ & 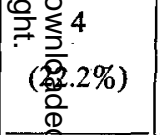 & $\begin{array}{c}9 \\
(50.0 \%)\end{array}$ & $\begin{array}{c}2 \\
(11.1 \%)\end{array}$ \\
\hline $\begin{array}{l}\text { Alcohol } \\
\text { abusers } \\
\text { with } \\
\text { dyspepsia } \\
\end{array}$ & 12 & $\begin{array}{c}11 \\
(91.7 \%)\end{array}$ & $\begin{array}{c}6 \\
(50.0 \%)\end{array}$ & $\begin{array}{c}8 \\
(66.6 \%)\end{array}$ & $\begin{array}{c}10 \\
(83.3 \%)\end{array}$ & - & $\begin{array}{c}2 \\
(16.6 \%)\end{array}$ & $\begin{array}{c}6 \\
(50.0 \%)\end{array}$ & $\begin{array}{c}17 \\
\text { points }\end{array}$ & $\begin{array}{c}\overrightarrow{\bar{\Phi}}_{1}^{1} \\
(1 \text { cases }) \\
(9.1 \%) \\
\end{array}$ & $\begin{array}{c}5 \\
(41.7 \%)\end{array}$ & $\begin{array}{c}4 \\
(11 \text { cases }) \\
(36.4 \%)\end{array}$ \\
\hline
\end{tabular}

Comparison of neuroticism, extroversion and mental deterioration in patients functional dyspepsia and controls and in alcohol abusers with and without dyspepsia

\begin{tabular}{|c|c|c|c|c|}
\hline \multirow[t]{2}{*}{, } & \multirow[t]{2}{*}{ Number of cases } & \multicolumn{2}{|c|}{$\begin{array}{l}\text { As measured by the } \\
\text { Maudsley Personality Inventory }\end{array}$} & \multirow{2}{*}{$\begin{array}{l}\text { Shipley } \\
\text { Hartford Retreat Scale } \\
\text { Beterioration Index }\end{array}$} \\
\hline & & Neuroticism & Extroversion & \\
\hline Controls & 9 & 18.2 & 29.2 & $2.66 \%$ \\
\hline Functional dyspeptics & 48 & 30.3 & 23.0 & $2.96 \%$ \\
\hline Alcohol abusers without dyspepsia & 15 & 26.1 & 24.5 & $16.7 \%$ \\
\hline Alcohol abusers with dysnensia & 12 & 34.4 & 26.8 & $8.5 \%$ \\
\hline Notes: ${ }^{*}=$ Statistically significant. $(\mathrm{p}<0.05)$ & : & & $\cdot$ & $\begin{array}{l}N \\
\text { N } \\
\text { O } \\
\text { V }\end{array}$ \\
\hline
\end{tabular}


The results of psychometric testing in the various groups are presented in Table II. No deterioration of mentation was expected in the F.D. group, and none was found. Compared with controls, however, patients with F.D. had a very significantly increased Neuroticism $(\mathrm{N})$ score, 30.3 compared with $18.2(\mathrm{p}<0.001)$. Patients with F.D. also had a reduced Extroversion (E) score, 23.0 compared with controls 29.2, but this was not significant $(0.5>\mathrm{p}>0.4)$. It was in even closer accord with the normal E score of 24.91 for English people generally.

Within the alcoholic group evidence of deterioration of mental function was expected and was found, but the apparently higher Deterioration Index (D.I.) in those without dyspepsia, 16.7 per cent, was not significantly different from those with dyspepsia 8.5 per cent. In this group those with dyspepsia had a similar E score to those without, but a significantly higher $\mathrm{N}$ score, 34.4 compared with 26.1 $(\mathrm{p}=0.05)$.

Analysis did not reveal any direct relationship between psychogenic or psychometric factors and organic clinical or laboratory findings, and data concerning these relationships are not presented. It is worth recording, however, that 36 out of 51 F.D's (70.6 per cent) showed definite epigastric tenderness on palpation. By contrast, in the alcoholic group only 2 out of 12 (16.6 per cent) with dyspepsia showed epigastric tenderness, and 1 out of 18 without dyspepsia showed epigastric tenderness. One control showed epigastric tenderness and it is possibly revelant that this individual scored the lowest Neuroticism score of the series, 2 and a high Extroversion score of 34.

\section{Discussion}

This investigation is an attempt to see whether, in patients who suffer from F.D., there are any inherited aetiological factors, to assess the effect of early environmental influence, and to trace the subsequent expression of symptoms including associated psychogenic conditions and personality types.

There is little evidence of any inherited tendency to psychogenic illness. The strikingly increased incidence of a family history of dyspepsia among patients with F.D. is more likely to be explained on the basis of early environmental influence. No attempt was made to distinguish between functional and organic dyspepsia in the family history. A similar association with a family history of abdominal pain was found by Hill and Blendis (1967) in adults and by Apley (1959) in children with non-organic abdominal pain.

Additional evidence that such early environmental influences play a part is the significant tendency for childhood emotional deprivation to be followed by F.D. in later life. This association has been previously demonstrated by Veselý and Horácková (1965) in relation to functional gastro-intestinal disturbances in general; 9 of 31 patients were found to have a "deprivation syndrome".

It is interesting, however, that the tendency for such factors to induce gastro-intestinal symptoms does not itself have an early expression, at least so far as recurrent bowel disturbance or recurrent vomiting in childhood are concerned. These two common conditions are often believed to have a partly or 
wholly psychogenic basis, but it appears they have little in common with the development of F.D. in later life. This is in keeping with the finding of Stenback and Siurala (1964) that in only a very few cases of functional dyspepsia did the symptoms begin in childhood.

When the F.D. syndrome does manifest itself, however, it is commonly accompanied by one or more of a constellation of phenomena which, themselves, may be partly psychogenic. Associated phenomena are shown to be headaches, insomnia, and a susceptibility to swings of mood which are sufficiently severe for the patient himself to acknowledge. Emotional lability at a subjective level affects two-thirds of patients with F.D.

The high degree of Neuroticism (or emotionality) found in the personalities of patients with F.D. is remarkable. "Neuroticism" refers to the general emotional lability of a person, his emotional over-responsiveness, and his liability to neurotic breakdown under stress. Extroversion, as opposed to introversion, refers to the out-going, uninhibited, social proclivities of a person (Eysenck 1959). The two dimensions are quite independent.

Normal mean scores for English people on the M.P.I. are given as $\mathrm{N}=19.39$ : $E=24.91$. Scores for the small control series in the present investigation differ insignificantly from these. $\mathrm{N}$ is lower, at 18.2 and $\mathrm{E}$ is higher at 29.5. These differences are not necessarily due only to chance, but may also be due to the fact that controls, like patients themselves, were taken from a community of relatively young British servicemen who may well not be representative of English people as a whole.

The mean $\mathrm{N}$ score among F.D. patients of 30.3 may be compared with the scores of prisoners (recidivists) 30.35; hysterics (hospital patients) 30.32; psycopaths (hospital patients) 35.58, and psychosomatics (hospital patients) 35.69 (Eysenck 1959). It confirms, but in more severe degree, the mean $N$ score of 27 found by Hill and Blendis (1967) in 20 patients with "non-organic" abdominal pain.

In attempting to deduce further evidence from the alcoholic group it is important to bear in mind that there is no general agreement as to the actual cause of dyspepsia in a patient suffering from alcohol abuse. It is not due to chronic gastritis. It could well be due to recurrent acute-on-chronic gastritis, but proof of this is lacking. The question now at issue is: if this dyspepsia has an organic cause, do psychogenic factors affect its expression? The data available are difficult to analyse.

Among the alcohol abusers the dyspetics, compared with non-dyspeptics are more neurotic on M.P.I. scoring, and more likely to suffer mood swings, but there is no evidence of an increased incidence of any of the other concurrent psychogenic features assessed. Reliance must not be placed on this, however, because it is possible that the alcohol itself might exert a direct effect on such features: for example, alcohol is a well established cause of both headaches and insomnia! The increased incidence of a history of psychiatric illness among those alcoholics destined to develop dyspepsia reinforces the idea that personality in some way influences the expresssion of dyspepsia in this organic syndrome. 
Here, however, familial and early childhood factors do not seem to be relevant. There probably exist more complex relationships between alcololism and dyspepsia as evidenced by the finding of Stenback and Siurala (1964) that there is a significantly higher incidence of alcohol addiction in prisoners with functional dyspepsia than in prisoners with duodenal ulcer.

The increase of D.I. generally among alcohol abusers is to be expected but it is very slight, probably due to the fact that they were not advanced cases. It is unrelated to the development of dyspepsia.

One way in which alcoholic patients with dyspepsia differed from patients with F.D. was in the infrequency with which epigastric tenderness was present. The fact that 70 per cent of F.D. patients have epigastric tenderness should warn against the common practice of looking on lack of tenderness as evidence in favour of a functional status.

\section{REFERENCES}

Aplfy. J. (1959). The Child with Abdominal Pains. Blackwell, Oxford.

BRUMmer, P. (1969). X-ray negative dyspepsia. Acta med. Scand. 185, 13-15.

EYSFNCK, H. J. (1959). Manual of the Maudsley Personality Inventory. University of London Press Ltd., London.

Hill. O. W. and RlfNDis, L. (1967). Physical and psychological evaluation of "non-organic" abdominal pain. Gut 8, 221-229.

ROBERTS, D. M. (1972). Chronic gastritis, alcohol and non-ulcer dyspepsia. Gut 13, 768-774.

Stenback, A. and Srurala, M. (1964). Duodenal ulcer and functional dyspepsia in prisoners. J. Psychosom. Res. 8, 127-135.

Vesely. K. T. and HnRACkOVA, E. (1965) Psychologic factors in the development of functional gastro-intestinal disturbances. Acta. Nerv. Sup. (Praha) 7, 190-191.

\section{Appointments to the Queen}

Brigadier J. Lapper, M.B., Ch.B., D.L.o., M.F.C.M., late Royal Army Medical Corps, was appointed Honorary Surgeon to the Queen, with effect from 1 August, 1977, in succession to Major-General H. S. Gavourin, M.B.E., M.B., B.S., F.R.C.O.G., who has retired.

Colonel R. A. Goodhead, T.D., M.B., B.S., Royal Army Medical Corps (T.A.V.R.), was appointed Honorary Surgeon to the Queen, with effect from 31 July, 1977, in succession to Colonel L. G. R. Ward, T.D., M.B., B.Chir., M.R.C.S., L.R.C.P., whose tenure has expired.

Colonel E. J. Bowen, L.D.S., late Royal Army Dental Corps, was appointed Honorary Dental Surgeon to the Queen, with effect from 4 July, 1977, in an existing vacancy.

\section{TO THE ARMY}

\section{Honorary Consultants}

Professor Harold Ellis, D.M., M.Ch., F.R.C.S., wàs appointed Honorary Consultant in Surgery to the Army, with effect from 24 October 1977, in succession to Mr. Robert Cox, C.B.E., M.B., F.R.C.S., who has retired.

\section{Royal College of General Practitioners}

Information has been received that the officers named below have been elected Fellows of the Royal College of General Practitioners.

COLONEL K. H. M. YOUNG, LIEUTENANT-COLONEL H. C. MASON, LIEUTENANT-COLONEL S. BERSTEIN. 